\title{
Influence of Hoxa5 on p53 Tumorigenic Outcome in
} Mice

\author{
Gaëlle Gendronneau, Margot Lemieux, \\ Mélanie Morneau, Josée Paradis, Bernard Têtu, \\ Nancy Frenette, Josée Aubin, and Lucie Jeannotte \\ From the Centre de Recherche en Cancérologie de l'Université \\ Laval, Centre Hospitalier Universitaire de Québec, L'Hôtel-Dieu \\ de Québec, Québec, Canada
}

Hox genes encode transcription factors of crucial importance in the pattern formation of a large spectrum of species. Several studies have now proposed a role for these developmental genes in cancer biology. It has been suggested that HOXA5 possesses growthsuppressive properties through activation of $p 53 \mathrm{ex}$ pression in human breast tissue. To assess the genetic cooperation that may exist between Hoxa 5 and $p 53$ in tumorigenesis, we generated Hoxa5/p53 compound mutant mice. The presence of Hoxa 5 null alleles increased the susceptibility of $p 53^{-/-}$mice to develop tumors with a high prevalence for thymic lymphoma, suggesting that the loss of function of the two genes collaborate in tumor formation. To extend our analysis to mammary tumorigenesis, we performed Hoxa $5 /$ p5 3 whole mammary gland transplantations into wild-type hosts. In the $p 53^{-/-}$background, the presence of one Hoxa 5 mutant allele had no impact on mammary tumor formation. In contrast, the complete loss of Hoxa 5 function influenced the tumorigenic outcome of $p 53^{+/-}$mammary glands. However, the collaborative nature of this interaction did not depend on the transcriptional regulation of $p 53$ by Hoxa 5 . Altogether, our data establish that Hoxa 5 and $p 53$ cooperate in mammary tumorigenesis in vivo. (Am J Pathol 2010, 176:995-1005; DOI: 10.2353/ajpath.2010.090499)

Tumorigenesis is a multistep process that reflects successive genetic alterations, some of which result in the activation of oncogenes and the loss of function of tumor suppressor genes. Mutations and loss of the p53 tumor suppressor gene are common genetic lesions in a large proportion of human cancers. ${ }^{1}$ The role of p53 in tumor susceptibility was further demonstrated by the character- ization of p53 mutant mice. p53-deficient mice are viable, but they are prone to develop a variety of spontaneous tumors that dramatically reduce their lifespan. ${ }^{2-4}$ Analyses of p53 compound mutant mice have also revealed that other genetic alterations involving various types of molecules, such as transcription factors, can participate with the loss of p53 function to tumor initiation and progression. $^{5-8}$

Genes responsible for the control of transcriptional programs during normal development significantly contribute to cancer. ${ }^{9}$ Both normal development and cancer rely on shifts in the delicate balance between cell growth and differentiation. Cancer can arise from the misappropriation of signaling pathways normally used to control cell fate decisions during development. Hox genes occupy a critical position in the developmental hierarchy. They encode transcription factors essential for regulating embryo pattern formation, morphogenesis, and organogenesis. ${ }^{10}$ Several studies have also enlightened the potential role of Hox genes in tumor development, invasion, and metastasis. In numerous types of tumor, expression of specific Hox genes is either increased or decreased, suggesting that they may be involved in tumor suppression or promotion. ${ }^{11-14}$ The exact role of Hox genes in tumorigenesis remains unclear, but a likely explanation can be that their misregulation alters expression of downstream effectors, causing improper activation of embryonic developmental cascade(s), thereby disrupting normal programs of growth and differentiation and leading to neoplasia. ${ }^{9}$ The ability of Hox genes to control morphogenesis implies their role in multiple cellular processes. Consequently, changes in Hox gene expression in various cancers have been associated to altered proliferation, angiogenesis, apoptosis, DNA

Supported by The Cancer Research Society (L.J.), a studentship from the Natural Sciences and Engineering Research Council of Canada (M.M.), and a Chercheur National Award from the Fonds de la Recherche en Santé du Québec (L.J.).

Accepted for publication October 21, 2009.

Supplemental material for this article can be found on http://ajp. amjpathol.org

Address reprint requests to Lucie Jeannotte, Ph.D., Centre de Recherche de L'Hôtel-Dieu de Québec, 9, rue McMahon, Québec, Québec, Canada G1R 2J6. E-mail: lucie.jeannotte@crhdq.ulaval.ca. 
repair, and metastatic behavior. ${ }^{15-19}$ Increased incidence of malignancies correlates also with ectopic cervical ribs in humans, a skeletal transformation associated with several loss-of-Hox gene function mutations, suggesting that Hox genes might be a molecular link between congenital anomalies and cancer. ${ }^{20}$

p53 gene expression has been shown to be under the control of HOX proteins. In the breast cancer cell line BT-20, constitutive HOXA10 expression up-regulates p53 expression, reducing the oncogenic potential of the cells. ${ }^{21}$ Transactivation and electrophoretic mobility shift assays have also revealed a direct binding of the HOXA5 protein to a putative HOX-binding motif in the p53 promoter region. ${ }^{22}$ In breast cancer cell lines and patient tumors, reduced HOXA5 protein levels correlate with the lack of p53 expression, supporting the idea that HOXA5 may possess growth-suppressive properties through activation of $p 53$ expression. ${ }^{22,23}$

We produced a Hoxa5 null mutant mouse line and demonstrated the crucial role of Hoxa5 in regulating morphogenesis and specifying regional identity along the embryonic axis. The phenotypic survey of the mutant mice has unveiled the crucial role of Hoxa5 in the development of several organs including the lung, gut, thyroid, and mammary glands. ${ }^{24-28}$ In the latter, the Hoxa5 mutation causes inappropriate precocious mammary epithelium development. Proliferation is augmented while accelerated differentiation occurs in aged nulliparous and pregnant females, preceding the abnormal secretory activity at parturition that underlies the incapacity of Hoxa5 ${ }^{-1-}$ dams to properly feed their pups. ${ }^{28}$ The accelerated lobuloalveolar epithelium development can be rescued by grafting of mutant mammary epithelium into wild-type fat pad. Conversely, reciprocal grafting experiments demonstrate that Hoxa5 ${ }^{-1-}$ stroma cannot support normal proliferation of wild-type epithelium. These data unveil the importance of Hoxa5 in the precise equilibrium between cell growth and differentiation and establish the essential contribution of Hoxa5 to mammary epithelium instruction via mesenchyme-epithelium crosstalk.

Hoxa5 null mutant mice are not prone to spontaneous tumorigenesis, indicating that the mutation is not a genetic lesion sufficient to initiate oncogenesis. However, the direct involvement of Hoxa5 in cancer was revealed by data showing that leukemogenesis induced by the CALM-AF10 fusion protein requires Hoxa5 up-regulation through the methylation of lysine 79 on histone $\mathrm{H} 3$ at the Hoxa5 locus by the methyltransferase hDOT1L. In bone marrow cells from Hoxa5 ${ }^{-1-}$ mice, CALM-AF10 fusion protein cannot cause leukemic transformation. ${ }^{13}$ Moreover, HOXA5 gene misexpression was reported in various human cancers. ${ }^{14,23,29,30}$ For instance, nearly $70 \%$ of human breast carcinomas have decreased HOXA5 protein levels compared with normal breast tissue. The loss of HOXA5 gene expression in human breast cancer also correlates with progression to higher-grade lesions, suggesting that it may act as a tumor suppressor gene.22,23 Thus, depending on the cellular context, either a gain or a loss of Hoxa5 gene expression may disrupt normal growth and differentiation programs causing neoplasia.
Our in vivo observations that Hoxa5 ${ }^{-1-}$ mice display hyperplasia and inappropriate differentiation of the mammary epithelium suggest a role for Hoxa5 in mammary tumorigenesis. ${ }^{28}$ This is further strengthened by the coordinated loss of p53 and HOXA5 expression in human breast tumors, which indicates that both genes can cooperate in tumorigenesis. ${ }^{22}$ To directly address this question, we generated Hoxa5/p53 compound mutant mice. Aside from the perinatal lethality associated with the Hoxa5 homozygous mutation, Hoxa5/p53 mutants mainly died from lymphomas similarly to p53 mutants. However, the loss of Hoxa5 function in p53 mutant mice increased the susceptibility to thymic lymphomas. The high predisposition of Hoxa5/p53 mutants to lymphoma limited their lifespan and precluded studies of tumors with longer latencies such as mammary tumors. To overcome this problem, we performed grafts of whole mammary glands from females carrying Hoxa5/p53 allelic combinations into wild-type hosts. We report here a cooperative action of Hoxa5 and p53 in mammary gland tumorigenesis.

\section{Materials and Methods}

\section{Mice, Genotyping, and Tissue Collection}

The establishment of the Hoxa5 mutant mouse line was previously reported. ${ }^{24}$ The p53-deficient mouse line was obtained from the Jackson Laboratory (Bar Harbor, ME). Both mutant lines were maintained in the 129/Sv inbred genetic background. Experimental animals were genotyped by Southern blot analysis as described. ${ }^{3,24}$

Hoxa5 mutant mice were interbred with p53 mutant mice to obtain double heterozygous animals (Hoxa5 $5^{+/-}$) $\left.p 53^{+/-}\right)$. The latter were intercrossed to generate mice of all possible allelic combinations. A total of $11 \mathrm{Hoxa}^{+/+} /$ p53 $3^{+/+}, 9 \mathrm{Hoxa}^{+/-} / \mathrm{p5} 3^{+/+}, 18 \mathrm{Hoxa5}^{-/-} / \mathrm{p} 53^{+/+}, 18$ Hoxa5 ${ }^{+/+} / p 53^{+1-}, 22 \mathrm{Hoxa5}^{+1-} / \mathrm{p} 53^{+1-}, 46 \mathrm{Hoxa5}^{-1-}$ / p53 $3^{+/-}, 26 \mathrm{Hoxa}^{+/+} / \mathrm{p} 53^{-/-}, 69 \mathrm{Hoxa}^{+/-} / \mathrm{p} 53^{-/-}$, and 15 Hoxa $^{-1-} / p 53^{-1-}$ mice were monitored daily during the first week, then weekly for 80 weeks, and sacrificed when overt tumor development was detected or when signs of morbidity were evident. Pathological and control tissues were excised, fixed overnight in cold $4 \%$ paraformaldehyde prepared in phosphate-buffered sulfate (PBS), processed, paraffin-embedded, and sectioned (6 $\mu \mathrm{m})$. In some cases, thymus, lymph node, and spleen specimens were processed for flow cytometric analyses (see below). All experiments were performed according to the guidelines of the Canadian Council on Animal Care and approved by the institutional animal care committee.

\section{Whole Mammary Gland Transplantation Studies}

Whole mammary gland transplantation experiments were performed as described. ${ }^{31}$ Entire inguinal glands containing both epithelium and stroma were removed from 4-week-old (on average) wild-type and Hoxa5/p53 compound mutant mice and transplanted in the place of the excised right inguinal gland of two 4-week-old wild-type 
female recipients. The left inguinal gland of the female recipients was also excised and reinserted as control to monitor the efficiency of the graft (autograft). Recipients were monitored daily during the first week, then weekly, and sacrificed when overt tumor development was detected or when signs of morbidity were evident. The transplanted glands (experimental and autograft) and the right endogenous thoracic gland were excised and processed for histological and immunohistological analyses.

\section{Histological, Immunohistochemical, and in Situ Hybridization Analyses}

Sections from tumors and control tissues were stained with hematoxylin eosin (H\&E) for evaluation by light microscopy. Further characterization of the tumors was assessed by immunohistochemistry with different cell markers: a rat monoclonal antibody against cytokeratin 8 (CK8, 1:20 dilution; gift from Dr. Normand Marceau, Université Laval) for luminal epithelial cells; a rabbit polyclonal antibody against cytokeratin 14 (CK14, 1:150; gift from Dr. Marceau) for myoepithelial cells; a mouse monoclonal antibody against $\alpha$-smooth muscle actin (1: 500; clone 1A4; Sigma, Oakville, Ontario, Canada) for myoepithelial cells and pericytes; a rat monoclonal antibody against CD31 (1:200; MEC13.3; Pharmingen, Mississauga, Ontario, Canada) for endothelial cells; a rabbit polyclonal antibody against vimentin (1:500; gift from Dr. Marceau) for fibroblasts; a rat monoclonal antibody against CD3 (1:100; Clone CD3-12; Serotec, Raleigh, NC) for T lymphocytes; and a rabbit monoclonal antibody against CD20 (1:20; Clone EP459Y; Abcam, Cambridge, MA) for B lymphocytes.

For all antibodies, antigen retrieval was performed by heat treatment in $10 \mathrm{mmol} / \mathrm{L}$ sodium citrate buffer $\mathrm{pH}$, except for CD31, which required an enzymatic digestion with trypsin-EDTA $(0.025 \%)$ at room temperature for 8 minutes. Endogenous peroxidases were inactivated in a $3 \% \mathrm{H}_{2} \mathrm{O}_{2}$ solution for 30 minutes. Nonspecific binding was then blocked with $3 \%$ normal goat serum at room temperature for 1 hour. Slides were incubated with the primary antibodies at the appropriate dilution overnight at $4^{\circ} \mathrm{C}$. Secondary antibody incubation with biotinylated goat anti-rabbit (Vector Laboratories, Burlington, Ontario, Canada), anti-rat, or anti-mouse (Jackson ImmunoResearch Laboratories, West Grove, PA) antibodies was performed for 30 minutes at a dilution of 1:200 or 1:500, followed by avidin-biotin complex reagent revelation (Vector Laboratories). Horseradish peroxidase activity was detected with the diaminobenzidine reagent kit (Zymed Laboratories, South San Francisco, CA). Slides were counterstained with Mayer's hematoxylin.

The RNA in situ hybridization protocol was essentially based on that of Ref. 32. A 850-bp Bg/ll-HindllI genomic fragment containing the $3^{\prime}$-untranslated region of the second exon of the murine Hoxa5 gene was used as a template for synthesizing a $\left[{ }^{35} \mathrm{~S}\right]$ UTP-labeled riboprobe. A minimum of three wild-type adult specimens was used for the analysis of Hoxa5 expression in the thymus and the spleen.
Microscopic analyses were performed with a Leica DMR microscope or a Wild M8 binocular (Leica Microsystems, Richmond Hill, Ontario, Canada) coupled to a QImaging camera. Image acquisition was done by using the QCapture software (QImaging, Surrey, British Columbia, Canada).

\section{Preparation and Flow Cytometric Staining of Cell Suspensions}

Cells from thymus, spleen, and lymph nodes (axillary, brachial, and inguinal) were released by mincing the tissues and filtrating the resulting suspensions through nylon sieves. Before filtration, cell suspensions were treated with $150 \mathrm{mmo} / \mathrm{L} \mathrm{NH}_{4} \mathrm{Cl}, 10 \mathrm{mmo} / \mathrm{L} \mathrm{KHCO}_{3}$, and $0.1 \mathrm{mmol} / \mathrm{L}$ EDTA to lyse erythrocytes and washed twice in RPMI 1640 medium containing $5 \%$ fetal bovine serum. Cells were counted by using a hemacytometer, suspended in PBS containing $1 \%$ fetal bovine serum (FACS medium), and stained with anti-CD4-fluorescein isothiocyanate (clone RM4-5; Pharmingen), anti-CD8-phosphatidylethanolamine (clone 53-6.7; Pharmingen), anti-B220-fluorescein isothiocyanate (clone RA3-6B2; Pharmingen), and anti-TcRßphosphatidylethanolamine (clone H57-597; Pharmingen) antibodies on ice for 25 minutes. Cells were washed twice in FACS medium before flow cytometric analysis on a EPICS $\mathrm{XL}$ cytometer (Beckman Coulter, Mississauga, Ontario, Canada). Listmode data were collected with live gating on $10^{4}$ relevant cellular events and analyzed by using Expo32 ADC software (Beckman Coulter).

\section{Quantitative RT-PCR Experiments}

Total RNA was isolated from paraffin-embedded whole mammary grafts by using the High Pure formalin-fixed, parafin-embedded (FFPE) tissue section RNA Micro kit (Roche Diagnostics, Laval, Québec, Canada) and cDNA was synthesized with Superscript II Reverse Transcriptase (Invitrogen, Burlington, Ontario, Canada) by using random primers. Real-time PCR was performed by using the Power SYBR Green PCR Master Mix (Applied Biosystems, Foster City, CA) and a thermal cycler ABI PRISM 7000. Samples were analyzed in triplicate. p53 and MIh1 transcripts were detected with the following primers overlapping exons 1 to 3 and exons 3 to 4, respectively: p53 forward 5'-TCTGAGCCAGGAGACATTTTCA-3'; p53 reverse 5'-AGCAACAGATCGTCCATGCA-3'; Mllh 1 forward 5'-GGATATTGTGTGTGAGAGGTTCACTAC-3'; and MIh1 reverse 5'-ACATGGGCCACATGGCTTAT-3'. The Rp/19 gene was used as control by using the primers Rp/19 forward 5'-GCTCGGATGCCTGAGAAGGT-3' and Rp/19 reverse 5'-TCCATGAGGATGGCGCTTGTT-3'.

\section{p53 Loss-of-Heterozygosity Analysis}

Genomic DNA was isolated from paraffin-embedded whole mammary grafts by using the QIAamp DNA FFPE Tissue kit (Qiagen, Mississauga, Ontario, Canada). Due to the small amount of DNA per sample, p53 loss of 
heterozygosity $(\mathrm{LOH})$ was determined by semiquantitative PCR analysis to specifically amplify the wild-type and mutant alleles with primers used for genotyping. ${ }^{33,34}$ The p53 wild-type allele was detected with exon 6 (p53 forward 5'-CCCGAGTATCTGGAAGACAG-3') and exon 7 (p53 reverse 5'-ATAGGTCGGCGGTTCAT-3') specific primers giving a band of $548 \mathrm{bp}$. The $p 53$ mutant allele was identified by using the primers NEOP53 forward 5'-CTTGGGTGGAGAGGCTATTC-3' and NEOP53 reverse 5'-AGGTGAGATGACAGGAGATC-3', for a 280 bp band. The intensity of $p 53$ wild-type and mutant PCR products was quantified by using ImageJ software $(\mathrm{NIH}$ Image). LOH was considered when the ratio between the intensity of the wild-type band versus the mutant band was $<0.5{ }^{35}$

\section{Statistical Analyses}

Mouse survival duration was defined as the time from birth until the animals died or became moribund. Kaplan-Meier survival curves were constructed and compared by using the log-rank test. For categorical variables, between-group differences were assessed by using Pearson's $\chi^{2}$ test or Fisher's exact test when appropriate. p53 and Mlh1 expression levels in mammary grafts were compared among independent groups by using the nonparametric method Kruskal-Wallis one-way analysis of variance by rank test with Monte Carlo estimation of the exact $P$ value. If the results from a comparison of multiple groups by using the Kruskal-Wallis test yielded a statistical significance, the permutation method (SAS Proc Multest) was applied to obtain the adjusted $P$ value for each group in pair-wise comparisons to the control group. Statistical analyses were performed by using the SAS 9.1.3 statistical software (SAS Institute, Cary, NC). A significance level of $<5 \%(P<0.05)$ was considered statistically significant.

\section{Results}

\section{Survival of Hoxa5/p53 Compound Mutant Mice}

To determine whether mutations in Hoxa5 and p53 cooperate during tumorigenesis, Hoxa5 homozygous mutant mice were interbred with p53 homozygous mutant mice to generate double heterozygous mutants $\left(\mathrm{Hoxa}^{+/-}\right)$ $\left.p 53^{+/-}\right)$. These animals were subsequently intercrossed to yield compound mutants of all possible Hoxa5/p53 allelic combinations. In the 129/Sv genetic background, the survival of Hoxa5 homozygous single mutants $\left(\right.$ Hoxa $\left.5^{-/-} / \mathrm{p} 53^{+/+}\right)$was less than a day for the majority of

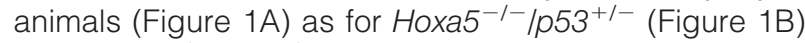

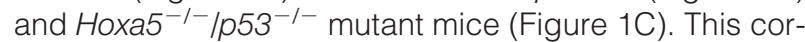
roborates the high rate of perinatal lethality associated with the Hoxa5 mutation previously reported. ${ }^{24,36}$ The survival curve of p53 homozygous single mutants $\left(\right.$ Hoxa $^{+/+} /{\left.\mathrm{p} 53^{-/-}\right)}$superimposed that of $\mathrm{Hoxa}^{+/-}$/ $p 53^{-1-}$ mice $(P=0.6309$; Figure $1 C)$. The median latency to morbidity and/or mortality of $\mathrm{Hoxa}^{+/+} / \mathrm{p} 53^{-/-}$ mice corresponded to 19 weeks while it was 17 weeks for Hoxa $5^{+/-} / p 53^{-1-}$ mice. As well, the survival curve of the
A

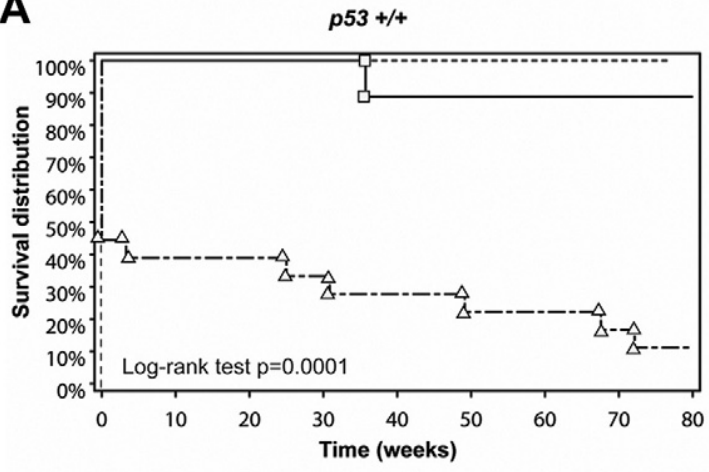

-- - - Hoxa5 +/+ (n=11) $\rightarrow \square-$ Hoxa5 $+/(n=9) \quad-\Delta-\cdot$ Hoxa5 $\%(n=18)$

B

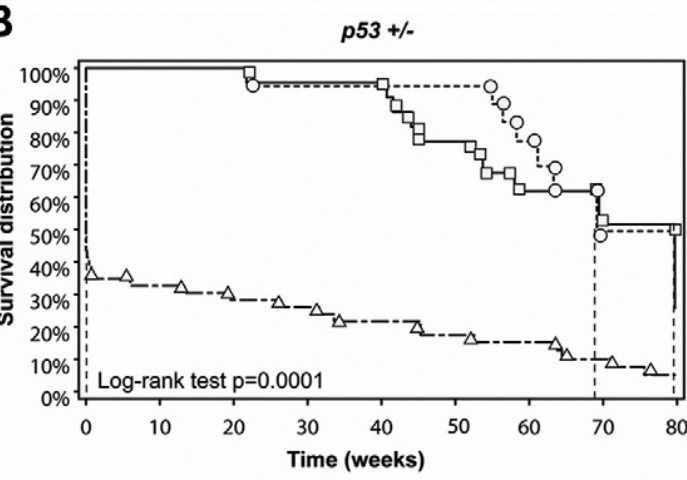

-- - Hoxa5 +/+ (n=18) $\rightarrow-$ Hoxa5 $+/-(n=22)-\triangle \cdots$ Hoxa5 $-/(n=46)$

C

p53\%

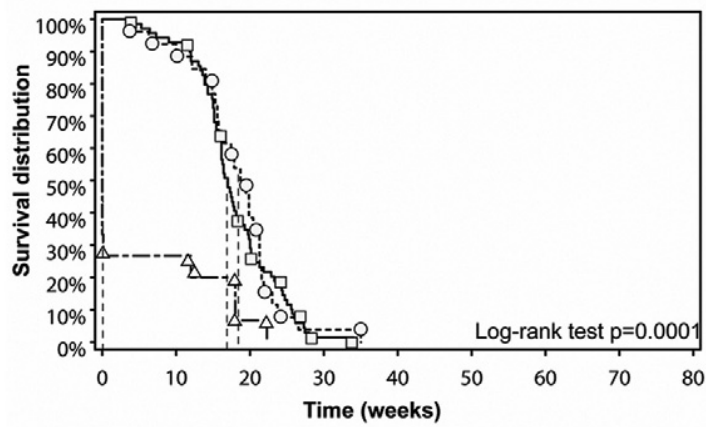

- - - Hoxa5 +/+ (n=26) $\neg-$ Hoxa5 +/- $(n=69)-\triangle-\cdot$ Hoxa5 $-/-(n=15)$

Figure 1. Kaplan-Meier curves showing survival of Hoxa $5 / p 53$ compound mutant mice monitored for 80 weeks. The $p 53$ genotype is indicated above each panel. Vertical dashed lines represent the median time at which $50 \%$ of the animals died. The median time of survival for $\mathrm{Hoxa}^{-1}$ is less than a day, regardless of the $p 53$ genotype (A-C). The median time of survival for $\mathrm{Hoxa}^{+/+} /$ $p 53^{-1-}$ and Hoxa $5^{+/-} / p 53^{-1-}$ mice is 19 and 17 weeks, respectively (C). The $P$ value was calculated by using the log-rank test; $n$ : number of mice analyzed per genotype.

Hoxa $5^{+/+} / p 53^{+/-}$animals was not significantly different from that of the double heterozygous mutants $(P=$ 0.5414; Figure 1B). The median latency to morbidity and/or mortality corresponded to 69 weeks for $\mathrm{Hoxa}^{+/+} /$ $p 53^{+/-}$mice and to 80 weeks for Hoxa $5^{+/-} / p 53^{+/-}$mice. Thus, the presence of one Hoxa5 mutant allele did not significantly impact on the survival of the animals regardless of the p53 genotype, indicating a lack of synergistic effect between p53 and Hoxa5 on survival. These data 
Table 1. Tumor Spectrum of Hoxa5/p53 Compound Mutant Mice

\begin{tabular}{|c|c|c|c|c|c|c|}
\hline \multirow[b]{2}{*}{ Genotype } & \multirow[b]{2}{*}{$n$} & \multirow{2}{*}{$\begin{array}{c}\text { Animals developing } \\
\text { tumors* }\end{array}$} & \multicolumn{4}{|c|}{ Tissues developing tumors $^{\dagger}$} \\
\hline & & & Lymphoid tissues & Testis & Mammary glands & Others $^{\ddagger}$ \\
\hline \multicolumn{7}{|l|}{$p 53^{+/+}$} \\
\hline Hoxa5 $5^{+/+}$ & 11 & 0 & & & & \\
\hline Hoxa5 $5^{+/-}$ & 9 & 0 & & & & \\
\hline $\begin{array}{l}\text { Hoxa5 } \\
053^{+1-}\end{array}$ & 8 & 0 & & & & \\
\hline Hoxa5 $5^{+/+}$ & 17 & $3(18)$ & $1(33)$ & & & $2(67)$ \\
\hline Hoxa5 $5^{+1-}$ & 21 & $3(14)$ & $2(67)$ & & & $1(33)$ \\
\hline $\begin{array}{l}\text { Hoxa5 } \\
\text { p53-1- }\end{array}$ & 16 & $2(13)$ & $1(50)$ & & & $1(50)$ \\
\hline Hoxa5 $5^{+/+}$ & 22 & $18(82)$ & $17(94)$ & $4(22)$ & $2(11)$ & $1(6)$ \\
\hline Hoxa5 $5^{+1-}$ & 62 & $61(98)$ & $57(93)$ & $7(11)$ & $4(7)$ & $1(2)$ \\
\hline Hoxa5 $5^{-1-}$ & 4 & $4(100)$ & $3(75)$ & $2(50)$ & & \\
\hline
\end{tabular}

Data presented as $n(\%)$ unless indicated otherwise. $n$, number of mice analyzed per genotype.

*Percentage relative to the number of animals analyzed.

tPercentage relative to the number of animals developing tumors.

₹Sarcomas affecting various tissues.

also demonstrated the predominant role of $p 53$ in longterm survival of Hoxa5/p53 compound mutants.

\section{Tumor Spectrum of Hoxa5/p53 Compound Mutant Mice}

The surviving Hoxa5 $5^{-1-} / p 53^{+/+}$mutant mice did not develop neoplastic lesion, showing that the loss of Hoxa5 function was not sufficient to initiate tumor formation (Table 1). These data agreed with our observations made over the years concerning the absence of tumor formation in Hoxa5 $5^{-1-}$ mice. The presence of either one or two Hoxa5 mutant alleles did not significantly impact the tumor susceptibility of $p 53^{+/-}$mice. In contrast, in $p 53^{-/-}$ animals, the introduction of one Hoxa5 mutant allele increased the number of mice developing tumors (82\% Hoxa $5^{+/+} / p 53^{-1-}$ versus $98 \%$ Hoxa5 $5^{+l-} / p 53^{-l-}$ mice; $P=0.0155)$. In all four Hoxa5 ${ }^{-1-} / p 53^{-1-}$ mice obtained, tumor formation occurred. These results suggest that the loss of Hoxa5 function increases tumor susceptibility of our $p 53^{-1-}$ cohort.

It is known that p53 mutant mice mainly develop lymphoid-derived tumors. ${ }^{2,3,37}$ Similarly, lymphomas were the most frequent tumors encountered in our $p 53^{-1-}$ cohort regardless of the Hoxa5 genotype (Table 1). In p53 $3^{-1-}$ mutants, we observed testicular tumors and few mammary gland tumors, independently of the Hoxa5 genotype. Some sarcomas were also observed in $p 53^{+/-}$ and $p 53^{-1-}$ cohorts. Other pathologies, such as kidney cysts and soft-tissue derived lesions, were detected. In p53 $3^{-1-}$ mice, lymphoid tumors were mostly found in the thymus and the spleen with few cases in the lymph nodes. However, when Hoxa5 mutant alleles were present, thymic tumors were more prevalent $\left(\mathrm{Hoxa}^{+/+} /\right.$ $p 53^{-1-}, 12$ of 17 mice $[71 \%]$; Hoxa5 $5^{+/-} / p 53^{-1-}, 54$ of 57 mice [95\%]; and Hoxa5 ${ }^{-1-} /{\mathrm{p} 53^{-1-}}^{-} 3$ of 3 mice [100\%]; $P=0.0281$ ), suggesting an increased susceptibility to thymus-derived tumors (Supplemental Table S1, see

Table 2. Tumor Development in Whole Mammary Grafts from Hoxa5/p53 Compound Mutants

\begin{tabular}{|c|c|c|c|c|}
\hline Genotype & $n$ & $\begin{array}{l}\text { Onset of tumor } \\
\text { formation } \\
(w k \pm S D)^{*}\end{array}$ & $\begin{array}{l}\text { Sacrifice after } \\
\text { transplantation } \\
\quad(\text { wk } \pm S D)\end{array}$ & Tumor type \\
\hline \multicolumn{5}{|l|}{$p 53^{+1+}$} \\
\hline Hoxa5 $5^{+1+}$ & 9 & & $73 \pm 5$ & No tumor \\
\hline Hoxa5 $5^{+1-}$ & 10 & & $72 \pm 10$ & No tumor \\
\hline $\begin{array}{l}\text { Hoxa5 }^{-1-} \\
\text { p53 }\end{array}$ & 16 & & $64 \pm 10$ & No tumor \\
\hline Hoxa5 $5^{+/+}$ & 10 & & $74 \pm 6$ & No tumor \\
\hline Hoxa5 $5^{+1-}$ & 9 & & $68 \pm 16$ & No tumor \\
\hline Hoxa5 $5^{-1-\dagger}$ & 9 & 46 & $67 \pm 18$ & $\begin{array}{l}\text { Lymphoma (1/9); mammary intraepithelial neoplasia (1/9); } \\
\text { carcinosarcoma (1/9) }\end{array}$ \\
\hline \multicolumn{5}{|r|}{ - } \\
\hline Hoxa5 $5^{+/+\ddagger \S}$ & 10 & $45 \pm 10$ & $53 \pm 8$ & $\begin{array}{l}\text { Angiosarcoma (9/10); carcinoma (1/10); adenocarcinoma } \\
(1 / 10) \text {; pseudosarcomatous carcinoma }(1 / 10)\end{array}$ \\
\hline Hoxa5 $5^{+1-\neq \S}$ & 10 & $45 \pm 9$ & $52 \pm 13$ & $\begin{array}{l}\text { Angiosarcoma (9/10); carcinoma ( } 1 / 10) \text {; carcinosarcoma } \\
\text { (1/10); pseudosarcomatous carcinoma }(1 / 10)\end{array}$ \\
\hline
\end{tabular}

$n$, number of successful mammary gland transplants analyzed per genotype.

*As determined by palpation; not applicable for lymphoma and mammary intraepithelial neoplasia.

tOne case of atypic lymphoid infiltration was observed.

¥One case of concomitant angiosarcoma and pseudosarcomatous carcinoma.

§One case of concomitant angiosarcoma and carcinoma. 


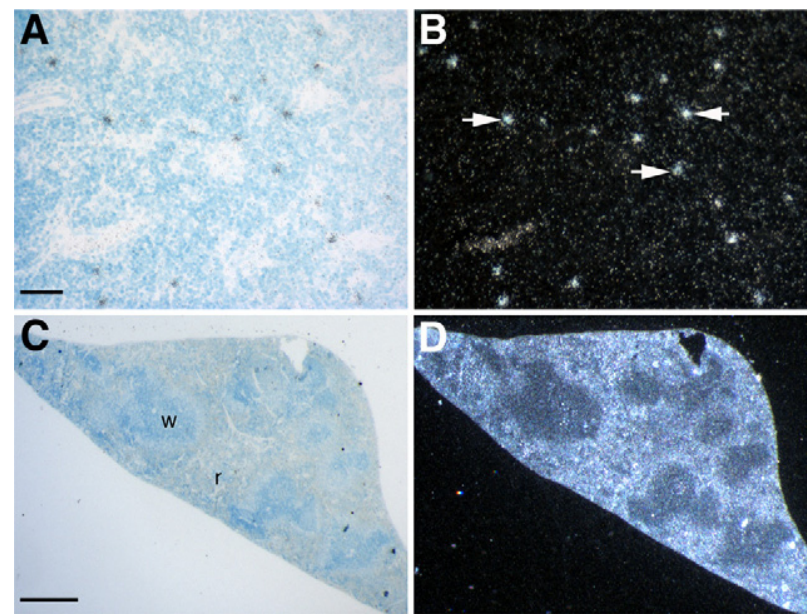

Figure 2. In situ hybridization of Hoxa 5 expression in thymus (A-B) and spleen $(\mathbf{C}-\mathbf{D})$ of wild-type adult mice. Bright-field views are shown in $\mathbf{A}$ and C. B: In the thymus, Hoxa 5 transcripts are detected in a punctate manner (arrows), while in the spleen (D) Hoxa 5 expression is found in the red pulp. $\mathrm{r}$, red pulp; w, white pulp. Scale bars $=50 \mu \mathrm{m}(\mathbf{A}) ; 500 \mu \mathrm{m}(\mathbf{C})$.

http://ajp.amjpathol.org). In contrast, spleen tumors were less abundant in the presence of Hoxa5 mutant alleles (Hoxa5 $^{+/+} / p 53^{-/-}, 10$ of 17 mice [59\%]; Hoxa5 $5^{+/-}$/ p53 ${ }^{-1-}, 11$ of 57 mice [19\%]; and $\mathrm{Hoxa}^{-1-} / \mathrm{p5} 3^{-1-}, 0$ of 3 mice $[0 \%] ; P=0.0056)$. No statistically significant difference was observed in the proportion of lymph nodederived tumors regardless of the Hoxa5 genotype in the $p 53^{-1-}$ cohort. To further characterize the lymphoid tumors, immunophenotyping performed by using B220, TcRB, CD4, and CD8 antibodies was done by flow cytometry. No anomalies were observed in the B and T cell populations in thymus, spleen, and lymph nodes of Hoxa5 $5^{-1-}$ mice, as previously reported (not shown). ${ }^{38}$ Independently of the Hoxa5 genotype, all spleen- and lymph node-derived tumors from the Hoxa5/p53 compound mutants were mainly from B-cell origin as they mostly expressed the B220 marker. In thymus-derived tumors, mature lymphoid $\mathrm{T}$-cell populations $\left(\mathrm{TcR}{ }^{+}\right.$ $\mathrm{CD}^{-} \mathrm{CD}^{+}$or $\mathrm{TcRB}^{+} \mathrm{CD}^{+}{ }^{+} \mathrm{CD}^{-}$) were detected in all four $\mathrm{Hoxa} 5^{+/+} / \mathrm{p} 53^{-/-}$specimens analyzed, whereas more immature T-cell populations $\left(\mathrm{TcRB}^{+} \mathrm{CD}^{+} \mathrm{CD}^{+}\right)$ were found in two of six Hoxa5 $5^{+1-} / p 53^{-1-}$ specimens. Thus, the loss of Hoxa5 function in a p53 mutant con- text may affect the susceptibility to develop thymic lymphoma.

As Hoxa5 appears to influence the frequency of the p53 lymphoid tumors, we assessed Hoxa5 expression in the thymus and the spleen by in situ hybridization. In adult thymus, Hoxa5 was expressed in a punctate manner (Figure 2, A and B), while in the spleen, Hoxa5 transcripts were mainly detected throughout the red pulp (Figure 2, $\mathrm{C}$ and D). Thus, Hoxa5 expression in spleen and thymus is compatible with a role, yet to be defined, for Hoxa5 in these tissues.

In summary, although the Hoxa5 mutation did not affect the tumor latency and tumor spectrum in Hoxa5/p53 mutants, it increased the susceptibility of $p 53^{-1-}$ mice to develop lymphoid tumors with a higher prevalence for thymic lymphoma. Altogether, these observations suggest that a genetic interaction may occur between Hoxa5 and $p 53$ in tumorigenesis.

\section{Development of Mammary Tumors in Hoxa5/p53 Whole-Gland Grafts}

Despite evidence suggesting a crucial role for p53 in human breast cancer, p53 mutant mice rarely develop mammary tumors. ${ }^{2,3}$ In our $p 53^{-1-}$ cohort, only $7 \%$ of the $p 53^{-1-}$ animals developing tumors presented mammary neoplasias, regardless of the Hoxa5 genotype (Table 1). The phenotype was also sex-independent. Out of the six cases, three angiosarcomas, one hemangioma, one mammary intraepithelial neoplasia (MIN), and one lymphoma were diagnosed.

The high predisposition of Hoxa5/p53 mutants to develop lymphoma limited their lifespan and precluded studies of tumors with longer latencies like mammary tumors. To directly address the genetic interaction between Hoxa5 and p53 in mammary tumor formation in vivo, we performed grafts of whole mammary glands from females of all possible Hoxa5/p53 allelic combinations into wild-type hosts, with the exception of $\mathrm{Hoxa}^{-1-}$ / $p 53^{-1-}$ specimens, which were never obtained. More than $95 \%$ of the grafts were accepted by the recipients. No tumor developed in the whole-graft transplants derived from mice of the following genotypes: Hoxa $5^{+/+} /$
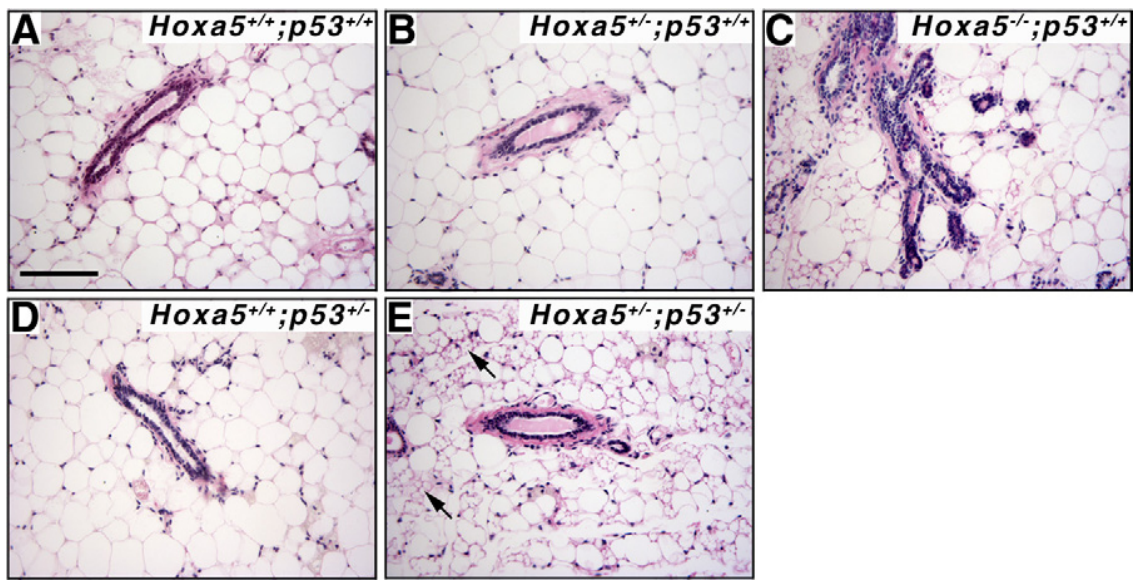

Figure 3. Histology of the mammary grafts from Hoxa $5 /$ p 53 allelic combinations that did not develop tumors. H\&E stained sections of representative mammary glands are shown. A: Control mammary graft displayed large adipocytes and ducts surrounded by a thin stroma. In $\mathbf{B}$ and $\mathbf{D}$, no obvious alterations were detected in Hoxa $5^{+/-} / p 53^{+/+}$(B) and Hoxa $5^{+/+} / p 53^{+/-}$ (D) grafts. C: Precocious lobuloalveolar development and epithelial hyperplasia were observed in $\mathrm{Hoxa}^{-/-} / \mathrm{p} 53^{+/+}$specimens as previously shown in Hoxa $5^{-1-}$ females. ${ }^{28} \mathbf{E}$ : Adipocytes with microvesicular fat droplets (arrows) and intense reactive stroma were often seen in $\mathrm{Hoxa}^{+/-}$ $p 53^{+/-}$grafts. Scale bar $=100 \mu \mathrm{m}$. 
A

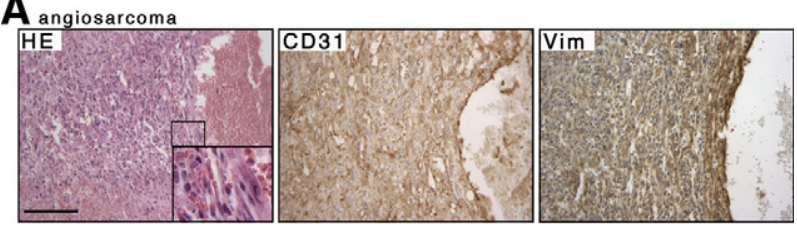

B carcinoma

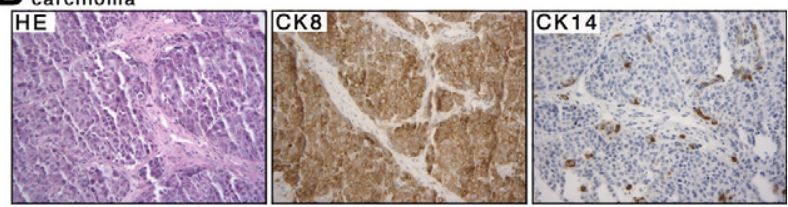

C adenocarcinoma

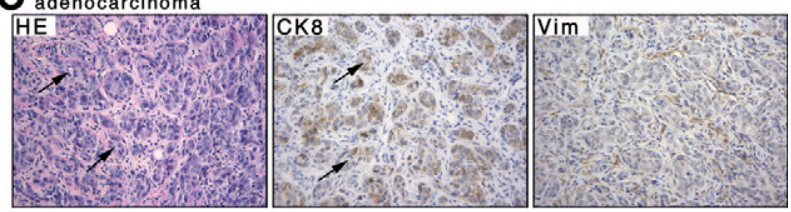

D pseudosarcomatous carcinoma

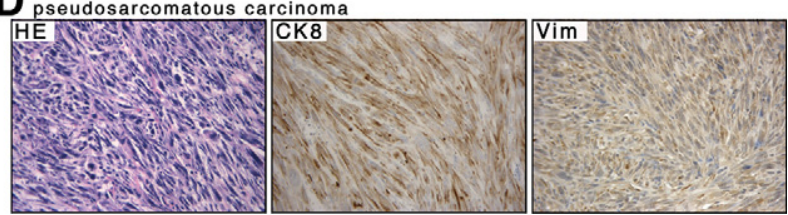

Figure 4. Neoplasias observed in $\mathrm{Hoxa}^{+/+} / \mathrm{p} 53^{-/-}$and $\mathrm{Hoxa} 5^{+/-}$, $p 53^{-/-}$mammary grafts. Hematoxylin \& eosin stained sections are shown on the left panel for each tumor type (A-D). A: The angiosarcoma, characterized by the presence of red blood cells within the sarcoma (inset), was positive for CD31, a marker of endothelial cells, and vimentin (Vim). B: The carcinoma was confirmed by its positivity for CK8 while being negative for CK14, a myoepithelial marker. C: The adenocarcinoma was composed of clusters of neoplastic epithelial cells positive for CK8 that are organized around small lumens (arrows) and surrounded by Vim-positive fibroblasts. D: The pseudosarcomatous carcinoma with typical fusiform epithelial cells costained for CK8 and Vim. Scale bar $=100 \mu \mathrm{m}$.

p53 ${ }^{+/+} ; \mathrm{Hoxa5}^{+/-} / \mathrm{p53^{+/+ }} ; \mathrm{Hoxa5}^{-/-} / \mathrm{p} 53^{+/+} ; \mathrm{Hoxa5}^{+/+} /$ $p 53^{+/-}$; and $H o x a 5^{+/-} / p 53^{+/-}$after 70 weeks on average (Table 2; Figure 3). In contrast, all $p 53^{-1-}$ mammary grafts developed tumors detectable approximately 45 weeks after transplantation, regardless of the Hoxa5 genotype (Table 2; Figure 4). The histology of the tumors revealed that angiosarcoma was the most prevalent tumor type observed in $\mathrm{Hoxa} 5^{+/+} / \mathrm{p5} 3^{-1-}$ (90\%) and Hoxa5 $5^{+/-} / p 53^{-1-}(90 \%)$ grafts, as confirmed by CD31, vimentin, and $\alpha$-smooth muscle actin immunostaining assays (Figure 4A; not shown). Few mammary grafts from the Hoxa5 ${ }^{+/+} / p 53^{-1-}$ and Hoxa5 $5^{+/-} / p 53^{-/-}$genotypes displaying angiosarcoma also developed either a carcinoma, as detected by CK8 immunostaining (Figure 4B), or a pseudosarcomatous carcinoma (Table 2; Figure 4D). In addition, an adenocarcinoma and a carcinosarcoma were detected in $\mathrm{Hoxa}^{+/+} / \mathrm{p5} 3^{-/-}$and Hoxa5 ${ }^{+/-} / \mathrm{p5} 3^{-1-}$ grafts, respectively (Table 2; Figure 4C; not shown). Thus, the presence of one Hoxa5 mutant allele has no major impact on mammary tumor latency and type in the p53 ${ }^{-1-}$ background, indicating a predominant role for p53 in mammary tumorigenesis.

All Hoxa5 $5^{+/+} / p 53^{+/-}$and Hoxa5 $5^{+/-} / p 53^{+/-}$mammary transplants remained tumor-free. In contrast, the homozygous loss of Hoxa5 function in a $p 53^{+/-}$context was
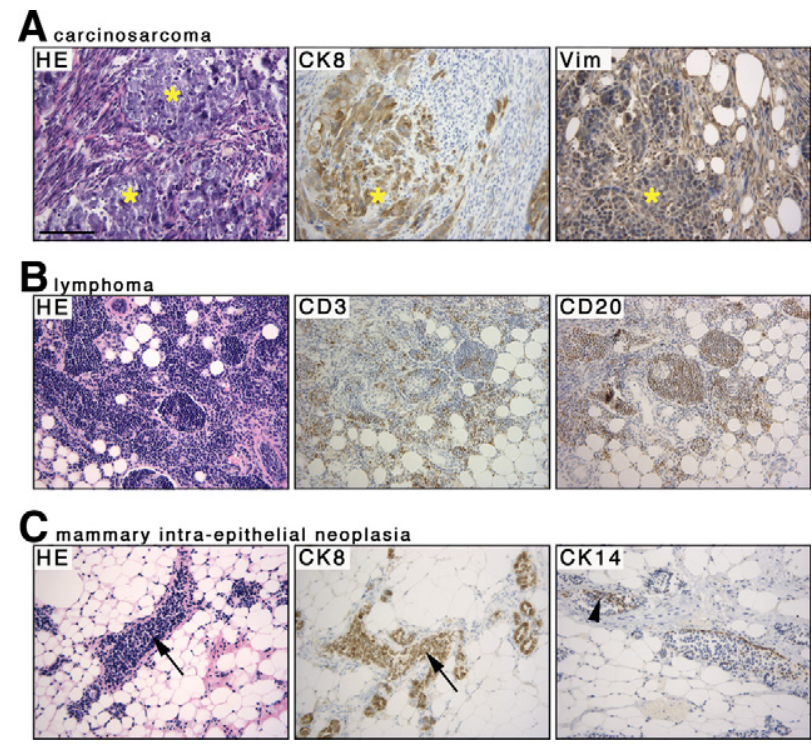

Figure 5. Characterization of Hoxa $5^{/-} / p 53^{+/-}$mammary tumors. Hematoxyline \& eosin stained sections are shown on the left panel for each tumor type (A-C). A: The carcinosarcoma with its sarcomatous and carcinomatous (asterisks) components is shown. Each component was revealed by CK8 (carcinoma) and by vimentin (Vim; sarcoma) immunostaining. B: The lymphoma was confirmed by immunostaining with the CD3 and CD20 lymphoid markers, labeling T- and B-cells, respectively. C: The mammary intraepithelial neoplasia was characterized by a CK8-positive epithelial hyperplasia within the mammary duct (arrows), the presence of CK14-positive myoepithelial cells (arrowhead), and the atypical nuclear cytology (not shown), suggesting a high-grade lesion. Scale bar $=100 \mu \mathrm{m}$.

associated with the development of Iymphoma (1 of 9), MIN (1 of 9), and carcinosarcoma (1 of 9; Table 2; Figure $5, \mathrm{~A}-\mathrm{C})$. The lymphoma was validated by immunostaining with lymphoid specific antibodies (Figure 5B). The MIN was characterized by an epithelial hyperplasia positive for the CK8 marker, the presence of $\mathrm{CK} 14^{+}$myoepithelial cells within the mammary duct, and the atypical nuclear cytology suggesting a high-grade lesion (Figure 5C). ${ }^{39}$ Thus, the loss of both Hoxa5 alleles may trigger mammary tumor development in a $p 53^{+/-}$background.

HOXA5 was reported to be a potential transcriptional regulator of p53 expression in human breast cancer. ${ }^{22}$ We thus monitored p53 expression levels in our mammary graft specimens by quantitative RT-PCR (Figure $6 \mathrm{~A})$. No significant change of p53 expression was detected in Hoxa5 $5^{-/-} / p 53^{+/+}$grafts compared with wildtype controls. The residual $p 53$ expression in $\mathrm{Hoxa}^{+/+} /$ $p 53^{-1-}$ tumor tissues was most likely due to the vascular contribution of the wild-type host to the tumor. Hoxa $5^{+/+} /$ $p 53^{+/-}$and Hoxa5 $5^{+/-} / p 53^{+/-}$mammary grafts showed a statistically significant reduction of $46 \%$ and $33 \%$, respectively, when compared with wild-type specimens, probably reflecting the haplo-insufficiency at the p53 locus. Likewise, a $43 \%$ decrease of p53 expression was detected in Hoxa5 $5^{-1-} / p 53^{+1-}$ specimens that did not develop tumors. The Hoxa5 $5^{-1-} / p 53^{+/-}$lymphoma and preneoplastic lesion MIN showed a similar reduction than the tumor-free specimens, whereas the Hoxa5 $5^{-1-} / p 53^{+/-}$ carcinosarcoma presented a pronounced decrease of p53 expression. These results suggest that the loss of Hoxa5 function did not alter p53 expression as shown in Hoxa5 ${ }^{-1-} / p 53^{+/+}$and Hoxa5 ${ }^{-1-} / p 53^{+/-}$grafts. Since we 
A

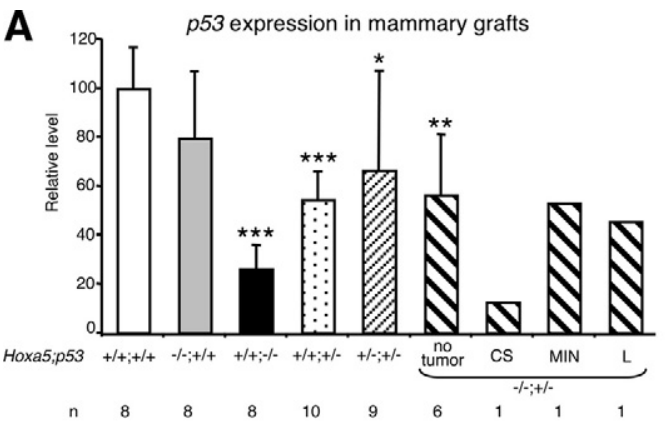

B

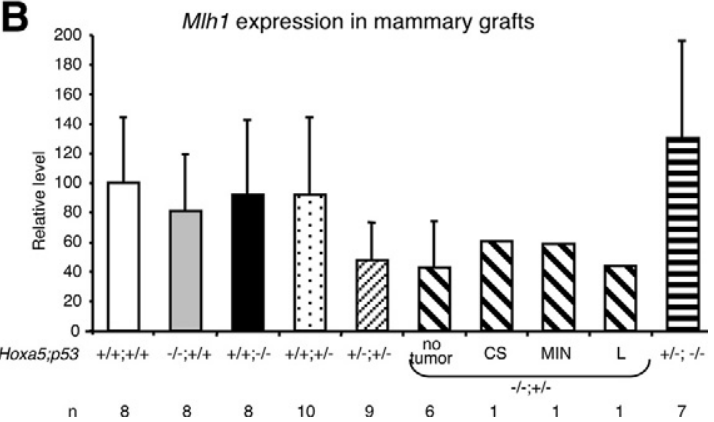

Figure 6. Quantitative RT-PCR analysis of $p 53$ and Mlb1 expression in Hoxa $5 /$ p53 mammary grafts. The genotypes of the mammary grafts and the number of specimens $(n)$ analyzed are indicated below each bar. A: Relative $p 53$ expression levels are represented. No significant change of $p 53$ expression was detected in Hoxa $5^{/-} / p 53^{+/+}$grafts compared with wild-type controls, while statistically significant reductions occurred in $\mathrm{Hoxa}^{+/+}$, $p 53^{-/-}$, Hoxa $5^{+/+} / p 53^{+/-}$, Hoxa $5^{+/-} / p 53^{+/-}$, and Hoxa $5^{/-} / p 53^{+/-}$ specimens. The Hoxa $5^{/-} / p 53^{+/-}$carcinosarcoma presented a pronounced decrease of $p 53$ expression. B: Relative Mlh1 expression levels are represented. No significant change of Mlh1 expression was detected in all specimens analyzed regardless of the genotype. CS, carcinosarcoma; L, lymphoma; ${ }^{*} P<0.05$; ${ }^{* *} P<0.01$; ${ }^{* * * *} P<0.001$.

could not rule out the possibility of a vascular and stromal contribution of the wild-type host to the grafts, we examined p53 expression in whole mammary glands from 4-month-old Hoxa5 ${ }^{-1-}$ nulliparous females (Supplemental Figure S1, see http://ajp.amjpathol.org). No statistically significant difference was observed supporting the notion that Hoxa5 is not a major regulator of p53 expression in the murine mammary gland.

The decreased p53 expression in the $\mathrm{Hoxa}^{-1-}$ / $p 53^{+/-}$carcinosarcoma suggests that $p 53 \mathrm{LOH}$ has occurred. To examine the status of the $p 53$ wild-type allele in the $H o x a 5^{-1-} / p 53^{+/-}$carcinosarcoma, we performed a semiquantitative PCR analysis (Supplemental Figure S2, see $h$ ttp://ajp.amjpathol.org). ${ }^{33,34}$ The intensity ratio of the band corresponding to the wild-type allele versus that of the mutant allele was superior to 0.5 in the $\mathrm{Hoxa}^{-1-}$, $p 53^{+/-}$tumor-free specimens, while that of the $\mathrm{Hoxa5}^{-1-}$ / $p 53^{+/-}$carcinosarcoma was inferior to 0.5 , supporting the notion of $\mathrm{LOH}$ in the $\mathrm{Hoxa}^{-1-} / \mathrm{p} 53^{+/-}$carcinosarcoma. ${ }^{35}$

As Hoxa5 may participate to the integrity of the genome through the regulation of the expression of the mismatch repair gene Mlh1, the loss of Hoxa5 function

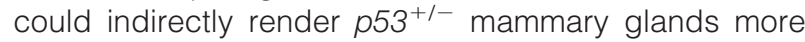
susceptible to a second hit mutation. ${ }^{17}$ Therefore, we examined MIh1 expression in our mouse mammary grafts. MIh1 expression was reduced by $52 \%$ in $\mathrm{Hoxa}^{+/-}$/ $p 53^{+/-}$grafts and by $57 \%$ in Hoxa5 ${ }^{-/-} / p 53^{+/-}$grafts, regardless of tumor formation (Figure 6B). However, these variations were not statistically significant. As well, no changes in Mlh1 expression were observed in all other genotypes analyzed.

In summary, whole mammary graft experiments clearly demonstrate the major role of the p53 gene in mammary tumorigenesis. They also establish that the loss of Hoxa5 function, despite no direct impact on p53 expression, can significantly contribute to mammary tumor formation in a $p 53^{+/-}$context, validating our hypothesis that Hoxa5 can cooperate with p53 in mammary neoplasia in vivo.

\section{Discussion}

In this report, we aimed to directly assess the genetic cooperation of Hoxa5 and p53 in tumorigenesis by generating Hoxa5/p53 compound mutant mice. In mice, the susceptibility to tumorigenesis and the spectrum of tumors that develop depend on the genetic background. ${ }^{2,37,40}$ The average lifespan of our $129 / \mathrm{Sv} p 53^{-/-}$ cohort was about 18 weeks, which is comparable with the $\sim 15$ to 17 weeks previously reported for the same genetic background. ${ }^{37,41} p 53$ has a predominant function in long-term survival of Hoxa5/p53 compound mutants. In contrast, the Hoxa5 mutation causes perinatal mortality with no major impact on p53-dependent survival of the compound mutants. The number of Hoxa5 ${ }^{-1-}$ surviving animals decreases in presence of p53 mutant alleles. This may reflect an additive action of both mutations on embryonic development as it is known that a small fraction of $p 53^{-1-}$ female embryos fail to develop normally. ${ }^{42,43}$ This consequence may account for the paucity of $\mathrm{Hoxa}^{-1-} / \mathrm{p} 53^{-1-}$ female mice obtained.

The tumor spectrum of our cohort of $p 53^{-1-}$ single mutant mice corresponds to that previously described for $p 53^{-1-}$ mice in the 129/Sv genetic background with lymphoma being the most frequent tumor occurring in $94 \%$ of the affected mice. ${ }^{37}$ In the presence of Hoxa5 mutant alleles, the tumor susceptibility of $p 53^{-1-}$ mice increases. Furthermore, the incidence of thymic lymphoma raises with the number of Hoxa5 mutant alleles in the $p 53^{-1-}$ background, suggesting some collaborative role between Hoxa5 and p53 in lymphomagenesis. Hoxa5 is expressed in restricted areas of the thymus that could correspond to regions of T-cell maturation, which may be consistent with our observation that some $\mathrm{Hoxa}^{+/-}$/ $p 53^{-1-}$ thymic lymphomas seem inclined to display immature T-cell populations. Altogether, these data indicate that the loss of Hoxa5 function could influence the susceptibility to develop thymic lymphoma. Inactivation of HOXA5 expression by hypermethylation was previously reported in myeloid and lymphoid malignancies in humans and strongly correlates with progression to blast crisis. ${ }^{30}$ Also, overexpression of HOXA5 in human patients suffering from $T$ acute lymphoblastic leukemia is associated with the production of the CALM-AF10 fusion protein. ${ }^{44}$ This was confirmed by genetic analysis showing that Hoxa5 up-regulation is required for inducing leukemia transformation mediated by CALM-AF10 fusion protein in mice. ${ }^{13}$ Thus, deregulated expression of Hoxa5 may contribute to malignant hemopathies. 
Angiosarcoma was the prevalent tumor type affecting the mammary glands of Hoxa5/p53 compound mutant mice (Table 1). In our whole graft experiments of $\mathrm{Hoxa}^{+/+} /$ $p 53^{-1-}$ and Hoxa5 $5^{+1-} / p 53^{-1-}$ mammary glands, all specimens develop tumors and most lesions consist of angiosarcomas (Table 2). Thus, the presence of one Hoxa5 mutant allele in the $p 53^{-1-}$ background has no major consequence on mammary tumor latency and type, showing the predominant role of the p53 homozygous mutation in the development of spontaneous mammary tumors. However, one limitation of our analysis was the lack of Hoxa5 ${ }^{-1-} / p 53^{-1-}$ whole mammary grafts due to the extremely low viability of Hoxa5 $5^{-1-} / p 53^{-1-}$ female mice that precluded the study of the impact of the homozygous loss of Hoxa5 function on mammary tumorigenesis in absence of $p 53$ function. The use of the Hoxa5 conditional mutant mouse line should provide a means to circumvent this hurdle by producing double homozygous null Hoxa5/p53 female donors. ${ }^{45}$

Breast cancer is a heterogenous disease, which includes a wide range of histological subtypes and a diversity of clinical behaviors and patient's outcome. ${ }^{46}$ In humans, primary breast angiosarcomas account for only $0.04 \%$ of all malignant breast tumors. ${ }^{47}$ They mainly arise in younger women. Secondary angiosarcomas occur most frequently after breast conservation therapy with radiation therapy $(0.15 \%){ }^{48}$ However, the risk is expected to raise as more women with breast cancer are treated with breast conserving therapy. ${ }^{49}$ Moreover, secondary angiosarcomas tend to have a poor prognosis. ${ }^{47}$ In the BALB/c background, $75 \%$ of $p 53^{-1-}$ whole mouse mammary gland transplants develop carcinomas or adenocarcinomas without report of occurrence of angiosarcoma. ${ }^{50}$ Thus, our mouse model in the $129 / \mathrm{Sv}$ genetic environment may provide an insightful system to study the genetic events responsible for this aggressive neoplastic lesion.

Adenocarcinoma and carcinoma were rarely observed

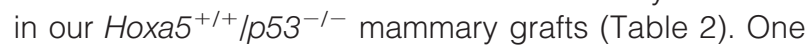
likely explanation for this difference in the mammary tumor spectrum may be the genetic background. The 129/Sv and C57BI/6 mouse strains are more resistant to mammary tumor development than the BALB/C mouse strain. ${ }^{40,50}$ Moreover, except for lymphomas and teratomas, soft-tissue sarcomas are the most prevalent tumors in 129/Sv p53 ${ }^{-1-}$ mice. ${ }^{41}$ The development of sarcomatous lesions, either angiosarcomas or carcinosarcomas,

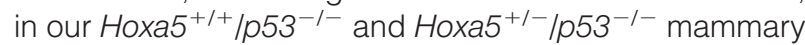
grafts may reflect the predisposition of the mice from the $129 / \mathrm{S} v$ strain to this type of tumors. It would also explain why only one case of adenocarcinoma occurred in the

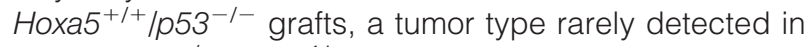
$129 / \mathrm{Sv} p 53^{-1-}$ mice. ${ }^{41}$

The impact of the loss of Hoxa5 function in $p 53^{+/-}$ mutant glands clearly demonstrates that Hoxa5 collaborates with p53 in mammary tumor formation. Our whole graft experiments show that the lack of both Hoxa5 functional alleles in $p 53^{+/-}$mammary glands causes neoplastic or preneoplastic lesions in $30 \%$ of the specimens,

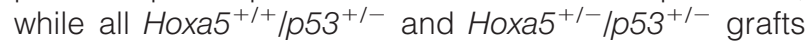
remain tumor-free. The tumor types detected correspond to mammary lymphoma, carcinosarcoma, and MIN. In humans, primary breast lymphoma is a rare entity, accounting for 0.04 to $1.1 \%$ of all breast tumors and for 1.7 to $2 \%$ of all non-Hodgkin's Iymphomas. ${ }^{51}$ It has a fair outcome. ${ }^{52}$ Human breast carcinosarcomas are also rare with an incidence estimated to 0.1 to $0.2 \%$ of breast carcinomas. ${ }^{53}$ However, they are very aggressive with a poor prognosis. True carcinosarcoma is strictly defined as a mixed tumor with both epithelial and mesenchymal components without a transition zone between the two elements. This type of tumor is often confounded with other metaplastic carcinomas, suggesting that they may be more abundant than reported. MINs are preneoplastic lesions that possess characteristics of both benign and malignant cells. In humans, these lesions affect epithelial tissues before or accompanying invasive carcinomas. ${ }^{39}$

While in human breast tumors and cell lines, HOXA5 is proposed to activate $p 53$ expression, our $p 53$ expression

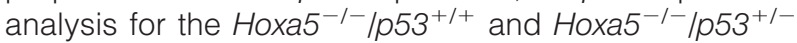
mouse mammary grafts does not support the notion that Hoxa5 significantly contributes to p53 transcriptional regulation (Figure 6A; Supplemental Figure S1, see http:// ajp.amjpathol.org). ${ }^{22}$ This may reflect that in mice, Hoxa5 is not a key regulator of p53 expression since $\mathrm{Hoxa}^{-1-}$ mice and mammary grafts never develop tumors. Moreover, the decreased p53 expression in the $\mathrm{Hoxa}^{-1-} /$ $p 53^{+/-}$carcinosarcoma was associated to $p 53 \mathrm{LOH}$ (Supplemental Figure S2, see http://ajp.amjpathol.org). Incidence of p53 LOH is frequent in human primary breast cancers and it was also reported in mouse mammary tumors. ${ }^{50,54}$

It was shown that HOXA5 may participate to the integrity of the genome of human breast cells through the transcriptional regulation of the mismatch repair gene MLH1. ${ }^{17}$ Our data rather indicate that the loss of Hoxa5 function does not impact MIh1 expression in mammary grafts. In fact, MIh1 expression levels are not significantly perturbed in all grafts analyzed regardless of the genotype. Although Mlh1 null mutant mice are prone to cancer, they mainly develop gastrointestinal tract and lymphoma tumors, with no reported occurrence of mammary tumors. ${ }^{55}$ As well, hMLH1 does not seem to play an essential role in human breast carcinoma. ${ }^{56}$ Together, these data are in agreement with our observations that tumor formation in Hoxa5/p53 mammary grafts does not involve Mlh1 misregulation.

In summary, our study endorses the hypothesis that Hoxa5 occupies a pivotal position in mammary gland homeostasis and tumorigenesis since its loss of function contributes with other genetic lesions to breast tumor formation. It now remains to define the mechanisms that underlie the genetic cooperation between Hoxa5 and p53 in mammary oncogenesis.

\section{Acknowledgments}

We thank Dr. Jean Charron for valuable comments on this article, Dr. Elisabeth Garin for her input in the initial stages of the project, Dr. Normand Marceau for providing antibodies, Dr. Pedro de Campos-Lima for support in 
quantitative RT-PCR analysis, Dr. Marilène Paquet for insightful comments, François Harel and Frederico Moreira for statistical analyses, and Juan Pablo Aragon and Audrey Garnier for their technical assistance.

\section{References}

1. Hollstein M, Rice K, Greenblatt MS, Soussi T, Fuchs R, Sorlie T, Hovig E, Smith-Sorensen B, Montesano R, Harris CC: Database of p53 gene somatic mutations in human tumors and cell lines. Nucleic Acids Res 1994, 22:3551-3555

2. Donehower LA, Harvey M, Slagle BL, McArthur MJ, Montgomery CA Jr, Butel JS, Bradley A: Mice deficient for p53 are developmentally normal but susceptible to spontaneous tumors. Nature 1992, 356:215-221

3. Jacks T, Remington L, Williams BO, Schmitt EM, Halachmi S, Bronson RT, Weinberg RA: Tumor spectrum analysis in p53-mutant mice. Curr Biol 1994, 4:1-7

4. Purdie CA, Harrison DJ, Peter A, Dobbie L, White S, Howie SE, Salter DM, Bird CC, Wyllie AH, Hooper ML, Clarke AR: Tumor incidence, spectrum and ploidy in mice with a large deletion in the p53 gene. Oncogene 1994, 9:603-609

5. Blyth K, Terry A, O'Hara M, Baxter EW, Campbell M, Stewart M, Donehower LA, Onions DE, Neil JC, Cameron ER: Synergy between a human c-myc transgene and p53 null genotype in murine thymic lymphomas: contrasting effects of homozygous and heterozygous p53 loss. Oncogene 1995, 10:1717-1723

6. Hundley JE, Koester SK, Troyer DA, Hilsenbeck SG, Subler MA Windle JJ: Increased tumor proliferation and genomic instability without decreased apoptosis in MMTV-ras mice deficient in p53. Mol Cell Biol 1997, 17:723-731

7. Jones JM, Attardi L, Godley LA, Laucirica R, Medina D, Jacks T, Varmus HE, Donehower LA: Absence of p53 in a mouse mammary tumor model promotes tumor cell proliferation without affecting apoptosis. Cell Growth Differ 1997, 8:829-838

8. Iozzo RV, Chakrani F, Perrotti D, McQuillan DJ, Skorski T, Calabretta B. Eichstetter I: Cooperative action of germ-line mutations in decorin and p53 accelerates Iymphoma tumorigenesis. Proc Natl Acad Sci USA 1999, 96:3092-3097

9. Abate-Shen C: Deregulated homeobox gene expression in cancer: cause or consequence? Nat Rev Cancer 2002, 2:777-785

10. Krumlauf R: Hox genes in vertebrate development. Cell 1994, 78:191-201

11. Cillo C: HOX genes in human cancers. Invasion Metastasis 1994, 14:38-49

12. Makiyama K, Hamada J, Takada M, Murakawa K, Takahashi Y, Tada M, Tamoto E, Shindo G, Matsunaga A, Teramoto K, Komuro K, Kondo $\mathrm{S}$, Katoh H, Koike T, Moriuchi T: Aberrant expression of HOX genes in human invasive breast carcinoma. Oncol Rep 2005, 13:673-679

13. Okada Y, Jiang Q, Lemieux M, Jeannotte L, Su L, Zhang Y: Leukaemic transformation by CALM-AF10 involves upregulation of Hoxa5 by hDOT1L. Nat Cell Biol 2006, 8:1017-1024

14. Takahashi O, Hamada J, Abe M, Hata S, Asano T, Takahashi Y, Tada M, Miyamoto M, Kondo S, Moriuchi T: Dysregulated expression of $\mathrm{HOX}$ and ParaHOX genes in human esophageal squamous cell carcinoma. Oncol Rep 2007, 17:753-760

15. Carrio M, Arderiu G, Myers C, Boudreau NJ: Homeobox D10 induces phenotypic reversion of breast tumor cells in a three-dimensional culture model. Cancer Res 2005, 65:7177-7185

16. Chen $\mathrm{H}$, Chung S, Sukumar S: HOXA5-induced apoptosis in breast cancer cells is mediated by caspases 2 and 8. Mol Cell Biol 2004, 24:924-935

17. Duriseti S, Winnard PT Jr, Mironchik Y, Vesuna F, Raman A, Raman V: HOXA5 regulates hMLH1 expression in breast cancer cells. Neoplasia 2006, 8:250-258

18. Rhoads K, Arderiu G, Charboneau A, Hansen SL, Hoffman W, Boudreau N: A role for Hox A5 in regulating angiogenesis and vascular patterning. Lymphat Res Biol 2005, 3:240-252

19. Rubin E, Wu X, Zhu T, Cheung JC, Chen H, Lorincz A, Pandita RK, Sharma GG, Ha HC, Gasson J, Hanakahi LA, Pandita TK, Sukumar S: A role for the HOXB7 homeodomain protein in DNA repair. Cancer Res 2007, 67:1527-1535
20. Anbazhagan R, Raman V: Homeobox genes: molecular link between congenital anomalies and cancer. Eur J Cancer 1997, 33:635-637

21. Chu MC, Selam FB, Taylor HS: HOXA10 regulates p53 expression and matrigel invasion in human breast cancer cells. Cancer Biol Ther 2004, 3:568-572

22. Raman V, Martensen SA, Reisman D, Evron E, Odenwald WF, Jaffee E, Marks J, Sukumar S: Compromised HOXA5 function can limit p53 expression in human breast tumours. Nature 2000, 405:974-978

23. Henderson GS, van Diest PJ, Burger H, Russo J, Raman V: Expression pattern of a homeotic gene: HOXA5, in normal breast and in breast tumors. Cell Oncol 2006, 28:305-313

24. Jeannotte L, Lemieux M, Charron J, Poirier F, Robertson EJ: Specification of axial identity in the mouse: role of the Hoxa-5 (Hox1.3) gene. Genes Dev 1993, 7:2085-2096

25. Aubin J, Lemieux M, Tremblay M, Bérard J, Jeannotte L: Early postnatal lethality in Hoxa-5 mutant mice is attributable to respiratory tract defects. Dev Biol 1997, 192:432-445

26. Aubin J, Déry U, Lemieux M, Chailler P, Jeannotte L: Stomach regional specification requires Hoxa5-driven mesenchymal-epithelial signaling. Development 2002, 129:4075-4087

27. Meunier D, Aubin J, Jeannotte L: Perturbed thyroid morphology and transient hypothyroidism symptoms in Hoxa5 mutant mice. Dev Dyn 2003, 227:367-378

28. Garin E, Lemieux M, Coulombe Y, Robinson GW, Jeannotte L: Stromal Hoxa5 function controls the growth and differentiation of mammary alveolar epithelium. Dev Dyn 2006, 235:1858-1871

29. Abe M, Hamada J, Takahashi O, Takahashi Y, Tada M, Miyamoto M, Morikawa T, Kondo S, Moriuchi T: Disordered expression of HOX genes in human non-small cell lung cancer. Oncol Rep 2006, 15:797-802

30. Strathdee G, Holyoake TL, Sim A, Parker A, Oscier DG, Melo JV, Meyer S, Eden T, Dickinson AM, Mountford JC, Jorgensen HG, Soutar $\mathrm{R}$, Brown R: Inactivation of HOXA genes by hypermethylation in myeloid and lymphoid malignancy is frequent and associated with poor prognosis. Clin Cancer Res 2007, 13:5048-5055

31. Brisken C, Park S, Vass T, Lydon JP, O'Malley BW, Weinberg RA: A paracrine role for the epithelial progesterone receptor in mammary gland development. Proc Natl Acad Sci USA 1998, 95:5076-5081

32. Jaffe L, Jeannotte L, Bikoff EK, Robertson EJ: Analysis of beta 2microglobulin gene expression in the developing mouse embryo and placenta. J Immunol 1990, 145:3474-3482

33. Iwakuma T, Tochigi Y, Van Pelt CS, Caldwell LC, Terzian T, Parant JM, Chau GP, Koch JG, Eischen CM, Lozano G: Mtbp haploinsufficiency in mice increases tumor metastasis. Oncogene 2008, 27:1813-1820

34. Yoshida K, Hirabayashi Y, Wada S, Wanatabe F, Wanatabe K, Aizawa $\mathrm{S}$, Inoue T: p53 (TRP53) deficiency-mediated antiapoptosis escape after 5 Gy X irradiation still induces stem cell leukemia in $\mathrm{C} 3 \mathrm{H} / \mathrm{He}$ mice: comparison between whole-body assay and bone marrow transplantation (BMT) assay. Radiat Res 2007, 167:703-710

35. Blackburn AC, McLary SC, Naeem R, Luszcz J, Stockton DW, Donehower LA, Mohammed M, Mailhes JB, Soferr T, Naber SP, Otis CN, Jerry DJ: Loss of heterozygosity occurs via mitotic recombination in Trp53 $3^{+/-}$mice and associates with mammary tumor susceptibility of the BALB/c strain. Cancer Res 2004, 64:5140-5147

36. Aubin J, Lemieux M, Tremblay M, Behringer RR, Jeannotte L: Transcriptional interferences at the Hoxa4/Hoxa5 locus: importance of correct Hoxa5 expression for the proper specification of the axial skeleton. Dev Dyn 1998, 212:141-156

37. Harvey M, McArthur MJ, Montgomery CA Jr, Bradley A, Donehower LA: Genetic background alters the spectrum of tumors that develop in p53-deficient mice. FASEB J 1993, 7:938-943

38. Weerkamp F, Luis TC, Naber BA, Koster EE, Jeannotte L, van Dongen JJ, Staal FJ: Identification of Notch target genes in uncommitted T-cell progenitors: no direct induction of a T-cell specific gene program. Leukemia 2006, 20:1967-1977

39. Cardiff RD, Anver MR, Gusterson BA, Hennighausen L, Jensen RA, Merino MJ, Rehm S, Russo J, Tavassoli FA, Wakefield LM, Ward JM, Green JE: The mammary pathology of genetically engineered mice: the consensus report and recommendations from the Annapolis meeting. Oncogene 2000, 19:968-988

40. Ullrich RL, Bowles ND, Satterfield LC, Davis CM: Strain-dependent susceptibility to radiation-induced mammary cancer is a result of differences in epithelial cell sensitivity to transformation. Radiat Res 1996, 146:353-355 
41. Donehower LA, Harvey M, Vogel H, McArthur MJ, Montgomery CA Jr, Park SH, Thompson T, Ford RJ, Bradley A: Effects of genetic background on tumorigenesis in p53-deficient mice. Mol Carcinog 1995, $14: 16-22$

42. Armstrong JF, Kaufman MH, Harrison DJ, Clarke AR: High-frequency developmental abnormalities in p53-deficient mice. Curr Biol 1995, 5:931-936

43. Sah VP, Attardi LD, Mulligan GJ, Williams BO, Bronson RT, Jacks T: A subset of p53-deficient embryos exhibit exencephaly. Nat Genet 1995, 10:175-180

44. Dik WA, Brahim W, Braun C, Asnafi V, Dastugue N, Bernard OA, van Dongen JJ, Langerak AW, Macintyre EA, Delabesse E: CALMAF10+ T-ALL expression profiles are characterized by overexpression of HOXA and BMl1 oncogenes. Leukemia 2005, 19:1948-1957

45. Tabariès S, Lemieux M, Aubin J, Jeannotte L: Comparative analysis of Hoxa5 allelic series. Genesis 2007, 45:218-228

46. Sarrio D, Rodriguez-Pinilla SM, Hardisson D, Cano A, Moreno-Bueno G, Palacios J: Epithelial-mesenchymal transition in breast cancer relates to the basal-like phenotype. Cancer Res 2008, 68:989-997

47. Glazebrook KN, Magut MJ, Reynolds C: Angiosarcoma of the breast. AJR Am J Roentgenol 2008, 190:533-538

48. Strobbe LJ, Peterse HL, van Tinteren H, Wijnmaalen A, Rutgers EJ: Angiosarcoma of the breast after conservation therapy for invasive cancer, the incidence and outcome: an unforeseen sequela. Breast Cancer Res Treat 1998, 47:101-109

49. Hodgson NC, Bowen-Wells C, Moffat F, Franceschi D, Avisar E: Angiosarcomas of the breast: a review of 70 cases. Am J Clin Oncol 2007, 30:570-573
50. Kuperwasser C, Hurlbut GD, Kittrell FS, Dickinson ES, Laucirica R, Medina D, Naber SP, Jerry DJ: Development of spontaneous mammary tumors in BALB/c p53 heterozygous mice: a model for Li-Fraumeni syndrome. Am J Pathol 2000, 157:2151-2159

51. Stasi R, Evangelista ML, Brunetti M, Bussa S, Maritati R, Turrini L, Taccogna S, Crescenzi A, Angelini F: Analysis of differential therapeutic strategies for primary breast lymphoma: two case reports. Med Oncol 2009, 26:22-26

52. Jeanneret-Sozzi W, Taghian A, Epelbaum R, Poortmans P, Zwahlen D, Amsler B, Villette S, Belkacemi Y, Nguyen T, Scalliet P, Maingon P, Gutierrez C, Gastelblum P, Krengli M, Raad RA, Ozsahin M, Mirimanoff RO: Primary breast lymphoma: patient profile, outcome and prognostic factors; a multicentre Rare Cancer Network study. BMC Cancer 2008, 8:86

53. Tokudome N, Sakamoto G, Sakai T, Sarumaru S, Okuyama N, Hori F, Horii R, Akiyama F, Tanabe M, Saito K, Takahashi K, Kasumi F: A case of carcinosarcoma of the breast. Breast Cancer 2005, 12:149-153

54. Varley JM, Brammar WJ, Lane DP, Swallow JE, Dolan C, Walker RA: Loss of chromosome 17p13 sequences and mutation of p53 in human breast carcinomas. Oncogene 1991, 6:413-421

55. Edelmann W, Yang K, Kuraguchi M, Heyer J, Lia M, Kneitz B, Fan K Brown AM, Lipkin M, Kucherlapati R: Tumorigenesis in Mlh1 and Mlh1/Apc1638N mutant mice. Cancer Res 1999, 59:1301-1307

56. Khilko N, Bourne P, Qi Y, Ping T: Mismatch repair genes hMLH1 and hMSH2 may not play an essential role in breast carcinogenesis. Int J Surg Pathol 2007, 15:233-241 